\title{
The Effect of Participation in Budgeting and Internal Control on Managerial Performance in Traditional Market Merchants' Association with Social Capital as Moderating Variable
}

\author{
Almira Nur'azmi Amrin ${ }^{1}$ Ietje Nazaruddin ${ }^{1, *}$ \\ ${ }^{1}$ Universitas Muhammadiyah Yogyakarta, Indonesia \\ *Corresponding author. Email: ietje.nazaruddin@umy.ac.id
}

\begin{abstract}
This study aims to determine the influence of budget participation and intern control through social capital as moderating variable towards the managerial performance of Asosiasi Pedagang Pasar Seluruh Indonesia (APPSI) which located in four traditional market type A in Bantul Regency namely APPSI Pasar Bantul, APPSI Pasar Imogiri, APPSI Pasar Piyungan, dan APPSI Pasar Niten. The result of this study is expected to contribute to informal organizations in the event of maximizing the activities of budget participation and intern control to be able to create a better managerial performance by applying social capital that has a decisive role in the process of institutional development. The data used in this study is primary data collected from 100 respondents who are the administrator of the APPSI in each market who have a direct role and essential responsibility to the organization. Data collection in this study using questionnaires and purposive sampling was chosen as the sampling method. This study uses multiple linear regression and interaction testing or Moderated Regression Analysis (MRA) as the analysis model, which is processed using the SPSS software application. The result of this study indicates that budget participation positively influenced organizational performance. Meanwhile, intern control does not affect organizational performance. Besides, social capital as the moderating variable significantly strengthens the positive effect of budget participation towards managerial performance. Meanwhile, social capital, as a moderating variable, does not enhance the positive influence of intern control on managerial performance.
\end{abstract}

Keywords: Budget Participation, Intern Control, Social Capital, Managerial Performance.

\section{INTRODUCTION}

The main objective of the development paradigm in Indonesia is to achieve social welfare, as stipulated in Article 33 of the 1945 Constitution, which is described in three points: 1) The kinship principle is the economical basis structured as a joint venture; 2) The state controls all-important production branches for the people livelihood at large; and 3) The land, water, and the wealth contained therein shall be controlled by the state and used as much as possible for people's prosperity. Referring to the three points of development goals above, the development concept can never be separated from human resources. An independent economy is a key to successful development. People who are willing and able to do business on their own are those who are aware that they cannot always depend on the state with all its limitations when the needs' demands are increasing. The society's independence in this economic sector can be the lubricant for this country's development wheels. One form of public awareness to move independently is to build informal organizations that grow from the community's initiatives. One fact of these informal organizations' emergence needs to be understood is that, every human being cannot live without having social relations with other human beings so that the need to be able to associate will arise, and informal organizations will be formed [1]. Informal organizations are built by individuals who have the same awareness that many problems in their environment can be appropriately resolved through cooperation among them, which is contained in an organizational structure. According to [2], social organizations are traditional and are built by people who have common interests and involve their members in a social contract. 
The current existence of informal organizations includes non-governmental organizations (NGOs), associations, and others. The Association of Indonesian Market Traders (APPSI) is a form of informal organization. APPSI is an independent informal organization as a forum for market traders to accommodate their aspirations, formulate their needs, and make joint efforts to realize organizational goals. The purpose of this APPSI organization, among others, is to fight for the market traders' rights and welfare throughout Indonesia. In this case, to achieve its goals, an organization must determine the right strategy in carrying out its programs; besides that, the organization also needs competent management to form an appropriate control system and planning [3].

Furthermore, an essential component in the planning process is the budget. In the budget preparation process, there is a process known as the budgetary participation approach. The participation's definition as an impetus from within a person to respond to situations that occur in his group so that he/she involves himself to contribute, both thoughts and ideas, to achieve predetermined goals and objectives [4]. The organization members' involvement is also accompanied by the responsibility for achieving the goals and objectives that have been determined. Specifically, this budgetary participation approach has been implemented by APPSI in Imogiri Market, Piyungan Market, Bantul Market, and Niten Market. It was reflected in the voluntary fee program and the market traders' involvement as APPSI's administrators and members in the organization's essential decision-making processes. This budgetary participation approach has proved to have a good influence on the APPSI's managerial performance of Imogiri Market, Piyungan Market, Bantul Market, and Niten Market. It impacted improving market infrastructure facilities and cleanliness in the market environment that provided comfort for both market traders and buyers.

Moreover, a strong and competent internal control system implementation is a no less important aspect of the budgetary participation approach. Internal control that has been implemented by APPSI of Imogiri Market included deliberation activities of the APPSI members of the Imogiri Market Commissariat, consisting the submission of financial reports, accountability, and internal activities implementation of the APPSI in Imogiri Market and channeling the Imogiri Market traders' aspirations through coordinators of each traders' zone. The author obtained information about the deliberation activities of the APPSI members of the Imogiri Market Commissariat from the interview results with the Chairperson, which was strengthened by documentary evidence in the form of financial reports, accountability reports, and reports of APPSI programs and activities. The internal control implementation mentioned above is in accordance with the internal control definition presented by [5], namely as an essential process in activities carried out continuously by the leader and all members to provide adequate confidence in the organizational goals' accomplishment through effective and efficient activities and the reliability of financial reporting

An informal organization, such as APPSI of Imogiri Market, could develop so strongly and independently, of course, due to several aspects. Apart from implementing modern organizational management principles (budgetary participation and internal control approaches), there is other aspects that dynamically contributed to strengthening the institutional of APPSI in Imogiri Market. This aspect is social capital in the form of values that build mutual trust among market traders in the management and membership of APPSI in Imogiri Market. The social capital role is one of the research contributions because no previous research has placed social capital as a moderating variable for budgetary participation and internal control implementation on managerial performance. The relationship between goals and performance is difficult to influence each other if there are no elements of mutual trust, mutual understanding, solidarity, and shared values and behaviors that bind each member in a working relationship, as well as a community that allows for cooperation, in which these are elements of the social capital concept.

This research is a replication of previous studies, which show that budgetary participation and internal control have a positive effect on managerial performance in local government agencies [6], [7]. Nevertheless, the difference between research conducted by the researchers and previous research is the addition of social capital variables, which have not been widely used as moderators in similar studies. Besides, the difference is in subjects and research objects that involved informal organizations as this empirical study's focus. This study offers a significant contribution regarding the existence of the social capital concept, which is considered capable of strengthening the influence of the strategic management implementation process in an organization in the form of budgetary participation and internal control on the organization's managerial performance. Therefore, informal organizations can realize institutional development by the success in achieving the organizational goals that have been determined together.

\section{LITERATURE REVIEW}

\section{Goal Setting Theory}

Previous research has shown that the effectiveness of an organization's performance could be obtained if it had specific and challenging targets; when targets were used to evaluate performance, there would be feedback that could form commitment [8]. Explicitly, one of the crucial 
constructs in goal setting theory is commitment [9]. This goal-setting theory is closely related to the organization members' budgetary participation role and internal control system. It means that to achieve the goals that have been set, not only one or two individuals work, but it takes the more organization members' participation to work together. Thus, goal setting theory influences the accuracy of budgeting, aligned with the organization's vision, mission, goals, and objectives.

\section{Participation in Budgeting}

A budget is a statement regarding the estimated performance to be achieved during a certain period of times and is expressed in financial measures [10]. A budget as a tool for planning, observing, predicting, and evaluating the performance of an entity to achieve its goals [11]. The process of preparing and compiling a budget is called budgeting. In the budget preparation process, an organization needs to formulate strategic planning in order to achieve organizational goals. Participation in budgeting is a budgeting activity with interrelated parties in an organization involved in the decision-making process, and the matters drawn up in the budget are adjusted to the organization's needs [7]. Participation in budgeting is a concept used to provide an overview of how far a subordinate in an organization is given access to determine his actions [12].

\section{Internal Control}

Internal control consists of a series of organizational policies set by management to support management objectives including by complying with these policies [13]. These management policies include preventing and discovering criminal acts such as corruption or theft, the accuracy and completeness of accounting reports and the presentation of reliable financial information which is held on time. The concept of internal control is an important process in an organization that is expected to be able to remove fraudulent acts such as corruption by implementing a transparent process so that operational activities carried out by an organization can be monitored by all members and can be accounted for periodically [6]. The process of preparing and compiling a budget is called budgeting. In the budget preparation process, an organization needs to formulate strategic planning in order to achieve organizational goals. Participation in budgeting is a budgeting activity with interrelated parties in an organization involved in the decision-making process, and the matters drawn up in the budget are adjusted to the organization's needs [7]. Participation in budgeting is a concept used to provide an overview of how far a subordinate in an organization is given access to determine his actions [12].

\section{Social Capital}

Social capital can be defined as a society that can work together to achieve the organization's common goals. Social capital as a person's ability to work together for a specific goal from a group or organization [14]. In other way, social capital can be defined as a society that can work together to achieve the organization's common goals. Social capital as a society capable of associating with others and forming a vital power, not only for economic life but also for every other social field [15].

\section{HYPOTHESIS DEVELOPMENT}

The phenomenon in the Association of Indonesian Market Traders (APPSI) at the Imogiri Market was that every trader had the right to propose to the APPSI management regarding common needs, such as market facilities' maintenance, traders' arrangement, and others. Traders' participation was not only limited to submitting proposals to the management but also the traders voluntarily gave part of their income to the APPSI organization as a jointly managed fund to meet all the market needs. Apart from being strengthened by theoretical explanations and descriptions of the phenomena that have been presented above, this research is supported by several previous studies from [5], [16], [17], and [18], which revealed that there was a significant positive effect of participation in budgeting on managerial performance. Based on the concept of participation in budgeting that is relevant to the researcher's goals, which is to test its effect on managerial performance, is based on goal-setting theory, which emphasizes the importance of the relationship between goals and performance and is complemented by phenomena that have been explained and supported by the results of previous studies. Based on these, the following hypothesis was derived:

$\mathrm{H}_{1}$ : Participation in budgeting has a significant positive effect on managerial performance.

Every organization must be able to implement internal control properly by considering all forms of decisions that can affect performance to ensure the accomplishment of organizational goals and objectives [19]. The internal control implementation could improve managerial performance, including decision-making strategies by those who had authority over it, namely in the context of this research were the Chairs of the APPSI Commissariat in Imogiri Market, Bantul Market, Piyungan Market, and Niten Market. Besides, the results of previous studies found that there was a significant influence of the organization's internal control on improving managerial performance [20], [21]. In their research, [5] explained that the internal control implementation is an important process in an organization expected to eliminate fraudulent acts, such as corruption by implementing a transparent process. Thus, reports on every operational activity carried out by an organization can be periodically accounted for and monitored by all organization members. As an effort to present information and implement a good 
communication system according to the internal control component indicators put forward by COSO, the APPSI management at Imogiri Market, Piyungan Market, Bantul Market, and Niten Market have implemented an information disclosure program for all organization members and built a communication system between management and all market traders as a means of accommodating all forms of complaints and constructive input for the common interest. Based on the descriptions of theories, arguments, and explanations for the phenomena that occurred, the second hypothesis was derived as follows:

$\mathrm{H}_{2}$ : Internal control has a significant positive effect on managerial performance.

The argument that the researchers could convey as the basis for deriving this third hypothesis was that to provide participation in the organization; every organization member needs to have a behavior that binds each party in a working relationship as one of the social capital concept elements [22]. The cooperation element between organization members as the meaning of this social capital concept becomes an amplifier in the participation in budgeting process. It is because every organization member involved and given space to contribute will have a high awareness and strong commitment to realizing the goals that have been set together (setting the goals). Thus, the organization members who have participated in the budgetary preparation will try their best to achieve organizational goals by improving managerial performance to measure the achievements they have achieved. Based on the description above, the researchers proposed the following hypothesis:

$\mathrm{H}_{3}$ : Good social capital will strengthen the positive influence of participation in budgeting towards managerial performance.

Every organization that can implement good internal control will be able to consider all forms of decisions that can affect managerial performance. Decision making is based on the organization's common interests, not on the certain group's interests. Social capital, in which there is an element of mutual trust, is needed as an aspect that strengthens the internal control implementation. The agreed organizational decision can foster a great sense of commitment in each of its members, where this commitment will lead each organization member to carry out their duties and comply with the rules that have been agreed upon together. Mutual trust among organization members as a social capital element can result in an acceptable organizational decision to all members, so this decision will become the basis of commitment for each organization member to comply with mutually agreed rules. Therefore, managerial performance can increase. Thus, in this fourth effect test, the following hypothesis was derived:
$\mathrm{H}_{4}$ : Good social capital will strengthen the positive influence of internal control implementation towards managerial performance.

\section{METHODOLOGY}

This research's samples were APPSI administrators in the traditional type-A market in Bantul Regency, including Imogiri Market, Bantul Market, Niten Market, and Piyungan Market. The APPSI management consisted of the commissariat chair, the daily administrators, the section coordinators, and the merchant zone coordinators.

Three types of variables in this study were the dependent variable, the independent variable, and the moderating variable. The dependent variable included a managerial performance with eight statement items relating to planning, investigation, coordination, evaluation, supervision, staffing, negotiation, and representation, adopted from research by [23]. The independent variables consisted of participation in budgeting and internal control. The participation in budgeting variable was measured by using a questionnaire containing six statement items by [24]. Meanwhile, the internal control variable was assessed using a questionnaire comprising of ten statement items, developed by [25] with the formal organizations' internal control approach. Furthermore, the social capital moderating variable was gauged using a questionnaire with ten statement items, developed in the study of [26].

A multiple linear regression test was used to test this study's first and second hypotheses. The multiple linear regression test itself is a test used to determine the effect of several independent variables on the dependent variable. As for the third and fourth hypotheses, this study employed multiple linear regression tests with the interaction test referred to as the Moderated Regression Analysis (MRA), a multiple linear regression equation, where the regression equation contains an interaction element. The multiple regression equation in this study is as follows:

\section{Equation Model I}

$K M=\alpha+\beta_{1} P P+\beta_{2} P I+\varepsilon \ldots \ldots \ldots \ldots \ldots$ (I)

\section{Equation Model II}

$$
\begin{aligned}
& \mathrm{KM}=\alpha+\beta_{1} \mathrm{PP}+\beta_{2} \mathrm{PI}+\beta_{3} \mathrm{MS}+\beta_{4} \mathrm{PP} * \mathrm{MS}+\beta_{5} \\
& \mathrm{PI} \mathrm{MS}+\varepsilon(\mathrm{II})
\end{aligned}
$$

\section{Explanation:}

KM : Managerial Performance (Y)

PP : Participation in Budgeting $\left(\mathrm{X}_{1}\right)$

PI : Internal Control $\left(\mathrm{X}_{2}\right)$

MS : Social Capital $\left(\mathrm{X}_{\mathrm{Mo}}\right)$

$\beta_{1}-\beta_{5} \quad$ : Regression Coefficient 


$$
\begin{aligned}
& \text { PP*MS } \quad: \text { Interaction between PP and MS } \\
& \text { PI*MS } \quad: \text { Interaction between PI and MS } \\
& \text { e : Error Term }
\end{aligned}
$$

\section{RESULTS AND DISCUSSION}

\section{Descriptive Statistic}

The data that could be used in the study was 100 out of 117 questionnaires distributed to respondents. Based on the calculation results, it could be concluded that all variables except managerial performance showed that the actual mean $>$ the theoretical mean. It indicated that the respondents in this study, namely market traders registered as APPSI administrators in the four traditional markets in Bantul Regency, had high perceptions of these variables.

Table 1. Descriptive Statistical of Research Variables

\begin{tabular}{|c|l|l|l|l|l|}
\hline \multirow{2}{*}{ Variable } & \multicolumn{3}{|c|}{ Theoretical } & \multicolumn{3}{c|}{ Actual } \\
\cline { 2 - 6 } & Estimate & Mean & Estimate & Mean & std. Dev. \\
\hline PP & $4-20$ & 12 & $11-20$ & 15.52 & 1.823 \\
\hline PI & $6-30$ & 18 & $18-30$ & 24.22 & 1.921 \\
\hline MS & $7-35$ & 21 & $19-35$ & 28.78 & 2.766 \\
\hline KM & $8-40$ & 24 & $8-36$ & 22.67 & 6.549 \\
\hline
\end{tabular}

Source: Results of Primary Data Processing, SPSS $15.0(2020)$

\section{Validity and Reliability Test}

Based on table 2, all variables had a KMO-MSA value higher than 0.50 , and all variable forming statement items had a loading factor value higher than 0.50. It indicated that all statement items above could be valid or suitable to be used as a measuring tool in this study. Cronbach's alpha value above 0.6 signified all reliable variables.

Table 2. Validity and Reliability Test Results

\begin{tabular}{|l|l|l|l|}
\hline Variable & $\begin{array}{l}\text { KMO } \\
\text { Value }\end{array}$ & $\begin{array}{l}\text { Loading } \\
\text { Factor Value }\end{array}$ & $\begin{array}{l}\text { Cronbach's } \\
\text { Alpha }\end{array}$ \\
\hline PP & 0.701 & $0.543-0.843$ & 0,697 \\
\hline PI & 0.597 & $0.543-0.741$ & 0,701 \\
\hline MS & 0.721 & $0.525-0.719$ & 0,743 \\
\hline KM & 0.862 & $0.659-0.883$ & 0,923 \\
\hline
\end{tabular}

Source: Results of Primary Data Processing, SPSS $15.0(2020)$

\section{Classic Assumption Test}

The normality test results specified that the Asymp. Sig (2-tailed) for the regression equation model I was 0.109 > alpha 0.05, and the value of Asymp. Sig (2tailed) for regression equation model II was $0.098>0.05$. thus, it could be concluded that the data residuals in the two regression equation models in this study were normally distributed. The multicollinearity test results on the first regression equation model met the criteria of being free from multicollinearity because each variable had a tolerance value of $0.796>0.1$ and a VIF value of $1.256<10$. Multicollinearity occurs in equations using moderation because there is an interaction between two or more variables. Multicollinearity was not a problem when applying moderated regression analysis in the second regression equation model in this study.

Based on the heteroscedasticity test results, it was known that all independent variables in both equation model I and equation model II had a sig value. > alpha 0.05 . Therefore, it could be concluded that the nonheteroscedasticity assumption in this study was fulfilled and showed that there were similarities in variance from one observation residual to another so that the regression model was considered good (homoscedasticity).

\section{Hypothesis Testing Results}

The multiple linear regression calculation results can be seen in table 3 . The test results of the budgetary participation effect on managerial performance showed that the regression coefficient $(\beta)$ was 0.829 and significant, meaning that $\mathrm{H}_{1}$ was accepted. Besides, the test results of the internal control influence on managerial performance revealed that the regression coefficient value was 0.374 but not significant, meaning that $\mathrm{H}_{2}$ could not be accepted. It implied that internal control did not have a significant positive effect on managerial performance.

Table 3. The Test Results of Equation Model I

\begin{tabular}{|l|l|l|}
\hline Variable & $\boldsymbol{\beta}$ & Sig. \\
\hline (constant) & 0.753 & 0.928 \\
\hline PP & 0.829 & 0.036 \\
\hline PI & 0.374 & 0.316 \\
\hline Simultaneous Significance Test Results (F Test) \\
\hline F Count & 4.684 \\
\hline Sig. & 0.011 \\
\hline \multicolumn{2}{|c|}{ Determination Coefficient Test Results } \\
\hline \multicolumn{2}{|c|}{ Adj. R Square } & 0.069 \\
\hline
\end{tabular}

Source: Results of Primary Data Processing, SPSS 15.0 (2020)

The Moderated Regression Analysis (MRA) test results are presented in Table 4 . The test results of the interaction between budgetary participation and social capital on managerial performance had a sig value of $0.010<$ alpha 0.05 , with a value of 0.293 (positive). This value could prove that $\mathrm{H}_{3}$ was supported, meaning that good social capital would strengthen the positive influence of budgetary participation on managerial performance. 
Table 4. The Test Results of Equation Model II

\begin{tabular}{|l|l|l|l|}
\hline \multirow{2}{*}{ Variable } & $\begin{array}{l}\text { Unstandardized } \\
\text { Coefficient }\end{array}$ & \multirow{2}{*}{ t } & \multirow{2}{*}{ Sig. } \\
\cline { 2 - 3 } & $\boldsymbol{\beta}$ & & \\
\hline (constant) & 68.656 & 0.974 & 0.333 \\
\hline PP & -7.995 & -2.390 & 0.019 \\
\hline PI & 3.175 & 1.099 & 0.275 \\
\hline MS & -2.372 & -0.936 & 0.351 \\
\hline PP*MS & 0.293 & 2.640 & 0.010 \\
\hline PI*MS & -0.089 & -0.882 & 0.380 \\
\hline Simultaneous Significance Test Results (F Test) \\
\hline F Count & 3.428 & \\
\hline Sig. & 0.007 & \\
\hline Determination Coefficient Test Results \\
\hline Adj. R Square & 0.109 \\
\hline
\end{tabular}

Source: Results of Primary Data Processing, SPSS $15.0(2020)$

Besides, the significant test results of the interaction effect of Internal Control with Social Capital on managerial performance had a sig value of $0.380>$ alpha 0.05 , with a value of -0.089 (negative). This value can prove that $\mathrm{H}_{4}$ was unsupported/rejected, indicating that good social capital did not strengthen the positive influence of internal control implementation on managerial performance.

The test results on $\mathrm{H}_{1}$ are also in line with goal setting theory that among many factors known to influence goal commitment, there are procedural elements of the goalsetting process; one of which is a participation element. It means that to achieve the goals that have been set, not only one or two individuals work, but it takes more organization members' participation to work together. An essential construct at the center of goal setting theory is commitment [9]. It suggests that if organization members are given the opportunity to contribute to setting goals, a high commitment will grow in the individual to improve their performance to achieve the goals set. This study's results are consistent with the research of previous studies, which showed that there was a significant positive influence of budgetary participation on managerial performance [6], [16], [17], [18].

All components of one main control objective conveyed by the Institute of Intern Auditors (IIA) must be owned by every organization, but their form and nature will be different and adapt to each organization's shape and nature. Informal organizations have a different system of internal control from formal organizations. Informal organizations have rules and regulations that are structured around similarities in behavior and habits (culture). The cultural control's nature in informal organizations is more flexible in the process of formulating policies, plans, legal procedures, and regulations. This flexibility is intended not to put too much pressure on and limit the movement of the organization's members. In informal organizations, internal control is aligned with the organization's culture [27]. This study's results are in line with previous research that internal control did not influence managerial (organizational) performance [25].

In line with the theory of goal setting, which has the main construction in the form of commitment, members of the organization who have been allowed to participate in the budget preparation process will do their best to achieve the organizational goals in a working budget. It is because organizational members have outstanding commitment based on their awareness of the organization's goals and the space that has been given to them. Thus, organization members will feel that their contribution is needed by the organization. Not all organization members have the willingness and ability to contribute and be involved in the budgeting process. Therefore, the social capital concept becomes a force due to the awareness and high moral values that can provide strength to encourage each member in an organization to associate and cooperate for a specific purpose.

The Indonesian Market Traders Association (APPSI), as this study's object, is an example of a social organization, which is a traditional organization in nature and built by people who have common interests and involve their members in a social contract. APPSI itself means an independent informal organization as a forum for market traders to accommodate their aspirations, formulate needs, and make joint efforts to realize organizational goals. Internal control in informal organizations is different from internal control in formal organizations. Internal control in this APPSI organization could not be compared to the internal control system usually applied to formal organizations, such as governments and companies (corporations). Based on the above explanation, the second hypothesis (H2) was rejected, indicating that the internal control system as applicable in the formal organizations, such as the internal audit process for financial statements, securing asset procedures, detection processes, monitoring, and supervising the use of organizational resources, and formulating strict and bureaucratic policies and rules, is very different to informal organization implementation. The informal organization has its internal control based on the culture inherent in every organization member. Furthermore, the mutual trust concept from social capital cannot strengthen the positive influence of internal control on managerial performance, not because there is no mutual trust between APPSI members of Imogiri Market, Bantul Market, Piyungan Market, and Niten Market located in Bantul Regency. However, researchers consider that social capital's mutual trust concept to moderate the positive influence of internal control on managerial performance had a very strong direct influence on managerial performance, so social capital was more appropriate to be an independent variable that had a direct effect on improving managerial performance. 
However, researchers believe that further and in-depth research is still needed on this matter.

\section{CONCLUSION AND IMPLICATION}

This study aims to examine and analyze the effect of budgetary participation and internal control on managerial performance with social capital as a moderating variable. This research was conducted to determine the factors influencing institutional development's success in informal organizations. In this study, the informal organizations as the research object were the Indonesian Market Traders' Association (APPSI) located in four type-A markets in Bantul Regency, including Imogiri Market, Bantul Market, Piyungan Market, and Niten Market. Based on hypothesis testing, it showed that budgetary participation had a significant positive effect on managerial performance at APPSI Imogiri Market, Bantul Market, Piyungan Market, and Niten Market. Meanwhile, internal control had no influence on managerial performance at APPSI in these four traditional markets. Besides, social capital has succeeded in strengthening the positive influence of budgetary participation on managerial performance at APPSI Imogiri Market, Bantul Market, Piyungan Market, and Niten Market. Nevertheless, social capital has not succeeded in having a positive influence on internal control on managerial performance at APPSI in Imogiri Market, Bantul Market, Piyungan Market, and Niten Market.

This study has limitations that require improvement and development for further research, including the sample area coverage selected in this study was only APPSI in four traditional markets of type A in Bantul Regency, so this study's results could not be generalized to the APPSI found in other markets. Besides, the independent variables used in this study were still very limited because the researchers only used three kinds of variables so that there were still many factors outside the research that could affect managerial performance improvement. Another limitation is that the questionnaire instrument on the internal control variable was not entirely in accordance with the organizational context under study, namely the Indonesian Market Traders' Association, an informal organization with a different internal control concept from the formal organizational control concept used in the questionnaire preparation.

Recommendations that the authors can convey to further researchers to improve and develop this research are expanding the research sample scope area of the APPSI organization found in other traditional markets. Second, the collecting data and information process can be combined by applying interview techniques so that researchers can determine more about respondents' perceptions. Furthermore, this research is still very limited to two independent variables and one moderating variable so that additional variables can be added to further research to develop the material discussion of factors affecting managerial performance in non-formal organizations.

\section{REFERENCES}

[1] D. C. O. Daniel, "Impact of Informal Groups on Organisational Performance," Int. J. Sci. Res. Manag., vol. 6, no. 09, Sep. 2018.

[2] D. Ancok, "Modal Sosial dan Kualitas Masyarakat," Univ. Gadjah Mada, p. 38, 2003.

[3] D. A. M. Sukmantari and I. W. P. Wirasedana, "Pengaruh Partisipasi Penganggaran dan Komitmen Organisasi pada Kinerja Manajerial dengan Kepuasan Kerja sebagai Variabel Intervening," EJurnal Akunt. Univ. Udayana, vol. 10.1, 2015.

[4] C. L. Kewo, "The Effect of Participative Budgeting, Budget Goal Clarity and Internal Control Implementation on Managerial Performance," Res. J. Financ. Account., p. 8, 2014.

[5] C. L. Kewo and N. N. Afiah, "Pengaruh Penganggaran Partisipatif, Kejelasan Sasaran Anggaran Dan Implementasi Pengendalian Intern terhadap Kinerja Manajerial Instansi Pemerintah Daerah Serta Implikasinya Pada Akuntabilitas Keuangan," p. 14, 2017.

[6] C. L. Kewo and N. N. Afiah, "Does Quality of Financial Statement Affected by Internal Control System and Internal Audit?," Int. J. Econ. Financ. Issues, 2017.

[7] R. Hasniasari and M. Sholihin, "Analisis Hubungan Penganggaran Partisipatif dan Kinerja: Pengujian Efek Mediasi Keadilan Persepsian dan Komitmen pada Lembaga Hukum Sektor Publik di Indonesia," J. Akunt. dan Keuang., vol. 16, no. 1, Jun. 2014.

[8] F. C. Lunenburg, "Goal-Setting Theory of Motivation," Int. J. Manag. Business, Adm., vol. 15, p. 6, 2011.

[9] A. Li and A. B. Butler, "The Effects of Participation in Goal Setting and Goal Rationales on Goal Commitment: An Exploration of Justice Mediators," J. Bus. Psychol., vol. 19, no. 1, pp. 3751, 2004.

[10] A. Halim and S. Kusufi, Teori,Konsep, dan Aplikasi Akuntansi Sektor Publik. 2017.

[11] S. I. Adeniyi, S. I. Adeniyi, And E. G. MieseighA, "Audit Tenure: An Assessment of its Effects on Audit Quality in Nigeria," Int. J. Acad. Res. Accounting, Financ. Manag. Sci., 2013.

[12] M. Ken, "The Relationship of Participation in Budget-Setting to Industrial Supervisor 
Performance and Attitudes: A Field Study," Account. Rev., 1975.

[13] H. A. Mire and A. Mukhongo, "Effects of internal control system on the organizational performance of remittance companies in Modadishu-Somalia," $J$. Bus. Manag., vol. 2, no. 9, pp. 153-167, 2016.

[14] G. J. Ikenberry and F. Fukuyama, "Trust: The Social Virtues and the Creation of Prosperity," Foreign Aff., 1996.

[15] S. Rahayu and H. A. Rozak, "Pengaruh Kepribadian dan Pemberdayaan Terhadap Kinerja Melalui Organizational Citizenship Behaviour Dengan Modal Sosial Sebagai Variabel Moderating," p. 19, 2015.

[16] K. M. D. Sakti, "The Effect of Budgetary Participation On Managerial Performance With Organizational Commitment, Organizational Culture, And Leadership Style As Moderating Variable," p. 19, 2017.

[17] B. Oyewo and G. Adeyeye, "Budgetary Participation and Managerial Performance in Public Sector Organisations: A Study from Nigeria," Ann. Spiru Haret Univ. Econ. Ser., vol. 18, no. 1, pp. 4776, Mar. 2018.

[18] P. A. Windasari and I. K. Sujana, "Pengaruh Penganggaran Partisipatif Pada Kinerja Manajerial Dengan Karakteristik Sistem Akuntansi Manajemen Sebagai Pemoderasi,” p. 28, 2016.

[19] S. Pratolo, "Pengaruh Audit Manajemen, Komitmen Organisasional Manajer, Pengendalian Intern Terhadap Penerapan Prinsip-Prinsip Good Corporate Governance dan Kinerja Badan Usaha Miliki Negara di Indonesia," J. Akunt. dan Investasi, p. 26, 2008.

[20] J. Fisher, "Contingency theory, management control systems and firm outcomes: past results and future directions," Behav. Res. Account., 1998.

[21] L. Mia and R. H. Chenhall, "The usefulness of management accounting systems, functional differentiation and managerial effectiveness," Accounting, Organ. Soc., 1994.

[22] L. Prusak and D. Cohen, "How to invest in social capital," in Creating Value with Knowledge: Insights from the IBM Institute for Business Value, 2005.

[23] G. Y. Putri, "Pengaruh Komitmen Organisasi dan Sistem Pengendalian Intern Pemerintan (SPIP) Terhadap Kinerja Manajerial SKPD,” p. 25, 2013.

[24] K.. Milani, "The Relationship of Participation in Budget-Setting to Industrial Supervisor
Performance and Attitudes: A Field Study," Account. Rev. 50, pp. 274-284, 1975.

[25] E. Santoso, "Pengaruh Sistem Pengendalian Intern Pemerintah, Pemanfaatan Teknologi Informasi dan Kompetensi Sumber Daya Manusia Terhadap Akuntabilitas Keuangan Daerah," Universitas Lampung, Bandar Lampung, 2016.

[26] A. D. Pratiwi, "Hubungan Modal Sosial Terhadap Kinerja Pegawai di Kantor Kecamatan Tamalanrea Kota Makassar," Univ. Hasanuddin Makassar, p. $143,2017$.

[27] C. M. Alina, S. E. Cerasela, and T. R. Andreea, "Internal Audit, Internal Control and Organizational Culture - Active Ingredients in Conquering the Crisis," Ovidius Univ. Ann. Ser. Econ. Sci., 2013. 